\title{
Regulation of prolactin secretion by $\alpha$-amino-3-hydroxy-5-methylisoxazole-4-propionic acid receptors in male rats
}

\author{
L C González, L Pinilla, M Tena-Sempere and E Aguilar \\ Department of Physiology, Faculty of Medicine, University of Córdoba, Córdoba, Spain \\ (Requests for offprints should be addressed to E Aguilar, Departamento de Fisiologia, Facultad de Medicina, Universidad de Córdoba, \\ Avda. Menéndez Pidal s/n, 14004-Córdoba, Spain; Email: Filagbee@lucano.uco.es) \\ (L C González and L Pinilla have contributed equally to this work)
}

\begin{abstract}
The secretion of PRL is controlled by different hypothalamic signals. Depending on the experimental model, PRL secretion increases or decreases after activation of $\mathrm{N}$-methyl-D-aspartic acid and kainate receptors. Recently we have described that activation of $\alpha$-amino-3-hydroxy5-methylisoxazole-4-propionic acid (AMPA) receptors inhibits PRL secretion in prepubertal male rats. The aim of present study was to examine (1) the physiological relevance of this finding, (2) the possible age-related changes observed after activation or blockade of AMPA receptors, (3) the specificity of the AMPA effect, (4) the hypothalamic and/or pituitary localization of AMPA action, and (5) the mechanism(s) of action of AMPA agonists.

In a first set of experiments, neonatal males (5 and 10 days old) and prepubertal (23 days old) male rats were injected with AMPA $(1,2.5$ or $5 \mathrm{mg} / \mathrm{kg})$ or the antagonist of AMPA receptors 1,2,3,4-tetrahydro-6-nitro-2,3dioxo-benzo (f) quinoxaline-7-sulfonamide (NBQX; $0 \cdot 25$ or $0.50 \mathrm{mg} / \mathrm{kg}$ ). Serum PRL concentrations decreased significantly 15 and $30 \mathrm{~min}$ after i.p. administration of AMPA in prepubertal male rats, while the inhibitory effect of AMPA was not observed in 5- and 10-day-old males. The effect of AMPA was abolished by NBQX but not by
\end{abstract}

MK-801 (a selective antagonist of NMDA receptors). NBQX alone $(0.25$ or $0.50 \mathrm{mg} / \mathrm{kg})$ had no effect on PRL release. In vitro, AMPA slightly stimulated PRL secretion by hemipituitaries from prepubertal males, suggesting that the hypothalamus is likely the site of action for the reported inhibitory action of AMPA on PRL release. In this sense, the blockade of AMPA effects in animals pretreated with domperidone (a dopaminergic antagonist) or $\alpha$-methyl-p-tyrosine (an inhibitor of dopamine synthesis) suggests that an increase in the release of hypothalamic dopamine is probably the mechanism involved in the effect of AMPA. In a second set of experiments, the effects of AMPA (2.5 mg/kg i.p.) and NBQX $(0.5 \mathrm{mg} / \mathrm{kg}$ i.p. and 20 or $40 \mathrm{nmol}$ i.c.v.) were tested in freely moving adult male rats sampled during periods of 2,3 or $6 \mathrm{~h}$. In contrast with data obtained in prepubertal rats, neither AMPA nor NBQX affected PRL secretion.

In conclusion, these data indicate that activation of AMPA receptors inhibits PRL secretion in prepubertal male rats. This effect probably involves the release of dopamine from the hypothalamus and disappears in adulthood.

Journal of Endocrinology (2000) 166, 669-675

\section{Introduction}

Hypothalamic control of prolactin (PRL) secretion involves different PRL-releasing (PRF) and -inhibitory factors (for review see Neill \& Nagy 1994). Excitatory amino acids (EAAs) are the major activating transmitters in the brain (van den Pol et al. 1990). In recent years, many authors have firmly established the role of EAA pathways in the control of neuroendocrine function (for review see Brann \& Mahesh 1997). The actions of EAAs are mediated by different post-synaptic receptors which include N-methyl D-aspartate (NMDA) receptors, kainate (KA) receptors, 2-amino-3-hydroxy-5-methylisoxazole- 4-propionic acid (AMPA) receptors, and metabotropic receptors (Collinbridge \& Watkins 1994, Brann \& Mahesh 1997). Depending on the experimental paradigm, NMDA and KA either stimulated or inhibited PRL secretion (Abbud \& Smith 1991, Luderer et al. 1993, Carbone et al. 1994, Pinilla et al. 1996, 1998). It has been proposed that the effects of glutamate agonists on PRL secretion depend on the previous circulating concentrations of the hormone, with a conversion of the PRL response from stimulation when basal secretion is low to an inhibitory effect in hyperprolactinaemic situations (Abbud \& Smith 1991). However, previous data from our laboratory indicated that, at least partially, the dual effect of NMDA on PRL 
secretion is independent of prior PRL concentrations (Pinilla et al. 1998).

AMPA receptors are involved in the steroid-induced luteinizing hormone (LH) surge (Ping et al. 1997) and activation of AMPA receptors stimulates gonadotrophinreleasing hormone $(\mathrm{GnRH})$ release from rat hypothalamic fragments and from immortalized $\mathrm{GnRH}$ neurones (Donoso et al. 1990, Spergel et al. 1994, Zuo et al. 1996). We reported very recently that activation of AMPA receptors stimulates growth hormone $(\mathrm{GH})$ release and inhibits PRL secretion in prepubertal male and female rats (González et al. 1999a,b). The experiments presented herein were set out to obtain additional information abouth the control of PRL secretion by AMPA receptors. Specifically we examine (1) the physiological relevance of this finding, (2) the possible age-related changes after activation or blockade of AMPA receptors, (3) the specificity of the AMPA effect, (4) the hypothalamic and/or pituitary localization of AMPA action, and (5) the mechanism(s) of action of AMPA agonists.

\section{Materials and Methods}

\section{Animals and drugs}

Wistar rats born in our laboratory were kept under controlled conditions of light (12 h light: $12 \mathrm{~h}$ darkness, lights on at $0700 \mathrm{~h})$ and temperature $\left(22^{\circ} \mathrm{C}\right)$, with free access to pelleted food (Pacsa Sanders, Seville, Spain) and tap water. On day 1 of life, each dam was left with eight pups. ( \pm )- $\alpha$-amino-3-hydroxy-5-methylisoxazole4-propionic acid (AMPA; an agonist of AMPA receptors), 1,2,3,4-tetrahydro-6-nitro-2,3-dioxo-benzo (f) quinoxaline-7-sulfonamide (NBQX; an antagonist of AMPA receptors), dizolcipine maleate (MK-801; an antagonist of NMDA receptors) and domperidone (a dopaminergic antagonist) were purchased from Research Biochemicals International (Natick, MA, USA). Diethyldithiocarbamate (DDC; an inhibitor of dopamine- $\beta$ hydroxylase); $\alpha$-methyl-p-tyrosine ( $\alpha$-MPT; an inhibitor of tyrosine hydroxylase) and 5-hydroxytryptophan methyl ester (5-HTP; a precursor of serotonin synthesis) were obtained from Sigma (Barcelona, Spain). Fluoxetine (an inhibitor of serotonin reuptake) was generously supplied by Dista (Barcelona,Spain). AMPA and NBQX were dissolved initially in a few drops of dimethylsulfoxide and domperidone in a few drops of methanol. Thereafter, the drugs were dissolved in saline up to the working concentration. The doses and route of administration of different drugs as well as the time-points for hormone measurements were selected based on the previously reported effectiveness (Negro-Vilar et al. 1979, Martin et al. 1995, Pinilla et al. 1998, 1999a, Gonzalez et al. 1999a,b) and the absence of behavioural changes. In addition, to analyse the effectiveness of AMPA to change PRL secretion after blockade of different receptor subtypes as well and in hyper-and hypo-prolactinaemic situations, NBQX, MK801, $\alpha$-MPT, DDC, 5-HTP and fluoxetine were injected prior to AMPA administration.

\section{Experimental designs}

Experimental procedures were approved by the Córdoba University Ethical Committee for animal experimentation and were conducted in accordance with the European Union norms for care and use of experimental animals.

\section{Neonatal and prepubertal males}

In experiment 1,23 -day-old male rats $(n=10$ per group) were killed 15, 30 and 60 min after i.p. injection of AMPA $(2.5$ or $5 \mathrm{mg} / \mathrm{kg}$ ) or vehicle and 60 and $120 \mathrm{~min}$ after i.p. injection of NBQX $(0.25$ and $0.50 \mathrm{mg} / \mathrm{kg})$ or vehicle. Special precautions were taken to avoid any stressful influences (e.g. all animals were handled daily for a week before the experiment and killed by the same person, the different drugs being injected at random). Trunk blood was collected in polystyrene tubes and after centrifugation $\left(1600 \mathrm{~g}\right.$ at $4^{\circ} \mathrm{C}$ for $\left.20 \mathrm{~min}\right)$ serum was collected, frozen and stored at $-20^{\circ} \mathrm{C}$ until use. Pituitaries were removed, dissected and homogenized in $1 \mathrm{ml}$ physiological saline containing urea $(2 \cdot 5 \mathrm{~mol} / \mathrm{l})$ by ultrasonic treatment (Haggi \& Aoki 1981). Samples were centrifuged for $20 \mathrm{~min}$ at $2800 \mathrm{~g}$ and the supernatant was frozen at $-20^{\circ} \mathrm{C}$ until analysis for hormone content. In experiment 2 , in order to detect the onset of the inhibitory effect of AMPA on PRL secretion, 5-, 10- and 23-day-old males $(n=10-12$ per group) were decapitated $15 \mathrm{~min}$ after administration of 1 or $2.5 \mathrm{mg} / \mathrm{kg}$ AMPA. In experiment 3 , in order to determine whether the inhibitory effect of AMPA was mediated by its specific receptors, 23-day-old males $(n=10$ per group) were injected with NBQX (antagonist of AMPA receptors; $0.5 \mathrm{mg} / \mathrm{kg}$ ) or MK-801 (antagonist of NMDA receptors; $0.25 \mathrm{mg} / \mathrm{kg}$ ) at $-60 \mathrm{~min}$ and with vehicle or AMPA $(2.5 \mathrm{mg} / \mathrm{kg})$ at $-15 \mathrm{~min}$. In experiment 4 , in order to detect possible actions of AMPA at pituitary level in the control of PRL secretion, anterior hemipituitaries (10-12 per group) were obtained from 23-dayold male rats and placed in glass scintillation vials (one per vial) in a Dubnoff shaker at $38^{\circ} \mathrm{C}$ in an atmosphere of 95\% $\mathrm{O}_{2}-5 \% \mathrm{CO}_{2}$. Each vial contained $1 \mathrm{ml}$ Dulbecco's Minimal Essential Medium (DMEM). After preincubation for $60 \mathrm{~min}$, the medium was replaced by fresh medium containing AMPA $\left(10^{-8}\right.$ to $\left.10^{-6} \mathrm{M}\right)$. Samples of medium were obtained at 60 and $120 \mathrm{~min}$ of the incubation period. In experiment 5 , in order to determine the possible involvement of dopamine on AMPA effects, 23 -day-old males ( $n=10$ per group) were injected with vehicle or domperidone $(1 \mathrm{mg} / \mathrm{kg}$ at $-60 \mathrm{~min})$ and with vehicle or AMPA $(2.5 \mathrm{mg} / \mathrm{kg}$ at $-15 \mathrm{~min})$. Other animals ( $n=10$ per group) were injected with $250 \mathrm{mg} / \mathrm{kg} \alpha-\mathrm{MPT}$ (inhibitor of dopamine synthesis) or $500 \mathrm{mg} / \mathrm{kg}$ DDC 
(inhibitor of dopamine- $\beta$-hydroxylase) $3 \mathrm{~h}$ before administration of vehicle or AMPA $(2.5 \mathrm{mg} / \mathrm{kg})$ and the animals were killed $15 \mathrm{~min}$ later. In experiment 6 , in order to evaluate the ability of AMPA to inhibit serotoninstimulated PRL secretion, 23-day-old males $(n=10$ per group) were injected s.c. with fluoxetine $(10 \mathrm{mg} / \mathrm{kg})$ and 5 -HTP $(100 \mathrm{mg} / \mathrm{kg}) 45 \mathrm{~min}$ before administration of vehicle or AMPA $(2.5 \mathrm{mg} / \mathrm{kg})$ and the animals were killed 15 min later.

\section{Adult male rats}

In this set of experiments, the role of AMPA receptors in the control of PRL secretion was studied in freely moving adult male rats. In experiment 7 , the animals $(n=6-8$ per group) were implanted with intracardiac canullae under sodium pentobarbital $(50 \mathrm{mg} / \mathrm{kg})$ anaesthesia. After surgery, the animals were placed directly in isolation test chambers for 5 days. In order to evaluate the role of AMPA and NBQX administered systemically, the animals were sampled for $2 \mathrm{~h}$ at 15 -min intervals. At the end of the first hour of sampling, the animals were injected i.p. with vehicle, AMPA $(2.5 \mathrm{mg} / \mathrm{kg})$ or NBQX $(0.5 \mathrm{mg} / \mathrm{kg})$. In experiment 8 , the animals were implanted with intracardiac and i.c.v. canullae under sodium pentobarbital $(50 \mathrm{mg} / \mathrm{kg})$ anaesthesia. In order to evaluate the role of NBQX administered i.c.v., groups of male rats $(n=10$ per group) were sampled at 5 -min intervals for periods of $3 \mathrm{~h}$ (1000-1300 h) as previously described (Carro et al. 1997). After the two initial samples, the animals received either vehicle or NBQX $(20 \mathrm{nmol}$ in $10 \mu \mathrm{l})$ through the i.c.v. route. During the sampling period, the volume of blood withdrawn was replaced hourly by a suspension of blood cells in sterile saline warmed at $38^{\circ} \mathrm{C}$. Other animals $(n=5-6$ per group) were sampled at $15-$ min intervals for periods of $6 \mathrm{~h}(1000-1600 \mathrm{~h})$.

\section{PRL measurements}

The PRL concentrations were measured in duplicate aliquots using a double-antibody method and radioimmunoassay (RIA) kits supplied by NIH (Bethesda, MD, USA). Rat-PRL-I-6 was labelled with iodine-125 by the chloramine $\mathrm{T}$ method (Greenwood et al. 1963) and rat-PRL-RP-3 was used as standard. Serum PRL concentrations were measured in $25-50 \mu \mathrm{l}$ aliquots and media from pituitary incubations were diluted $1 / 100$ and $10 \mu \mathrm{l}$ of this solution used for PRL measurements. Intra- and interassay variations were $9 \%$ and $12 \%$ respectively, and assay sensitivity was $10 \mathrm{pg} /$ tube.

\section{Statistical analysis}

Data are expressed as means \pm S.E.M. Data were homogeneous and no transformation was carried out. Intergroup differences were determined by one- or two- way analysis of variance (ANOVA) followed by Tukey's test. Specifically, we used two-way ANOVA to analyse interaction between different variables in experiment 1 (serum PRL concentrations at different times after different treatments), experiment 2 (serum PRL concentrations at different ages after different treatments), experiment 4 (PRL concentrations after different times of incubation in the presence of different doses of AMPA), and experiments 5 and 6 (effects of AMPA in animals previously treated with different drugs). Assessment of pulsatile PRL secretion was carried out using the ULTRA program (E Van Cauter, Department of Medicine, University of Chicago, Chicago, IL, USA).

\section{Results}

Effects of $A M P A$ and NBQX on serum and pituitary PRL concentrations in 23-day-old male rats (experiment 1)

Administration of AMPA decreased PRL concentrations significantly $(P \leq 0 \cdot 01$, two-way ANOVA). The analysis of interactions evidenced that the effect was significant 15 and $30 \mathrm{~min}$ after administration of 2.5 or $5 \mathrm{mg} / \mathrm{kg}$ AMPA and returned to basal levels $60 \mathrm{~min}$ after drug injection (Fig. 1). Serum concentrations of PRL remained unchanged in male rats 1 and $2 \mathrm{~h}$ after administration of NBQX (data not shown). Pituitary concentrations of PRL remained unchanged after AMPA or NBQX administration (data not shown).

Effects of AMPA on serum PRL concentrations in infantile rats (experiment 2 )

Serum PRL concentrations were higher in 23-day-old animals than in neonatal ones $(P \leq 0 \cdot 01$, two-way ANOVA). The analysis of interactions evidenced that the inhibitory effect of AMPA was not observed in 5- and 10-day-old males (Table 1).

Effects of pretreatment with $N B Q X$ and $M K-801$ on the inhibitory action of AMPA on PRL secretion (experiment 3)

Since it has been suggested that the same agonist might bind to more than one receptor subtype (Zanisi et al. 1994), we checked the effects of AMPA in the presence of NBQX (antagonist of AMPA receptors) and MK-801 (antagonist of NMDA receptors). In this experiment there was evidence that antagonization of NMDA receptors with MK-801 and activation of AMPA receptors significantly $(P \leq 0 \cdot 01)$ inhibited PRL secretion, the effects of MK-801 and AMPA being additive. NBQX blocked the AMPA action and the serum PRL concentrations were similar in animals treated with NBQX or NBQX+AMPA (Table 2). 

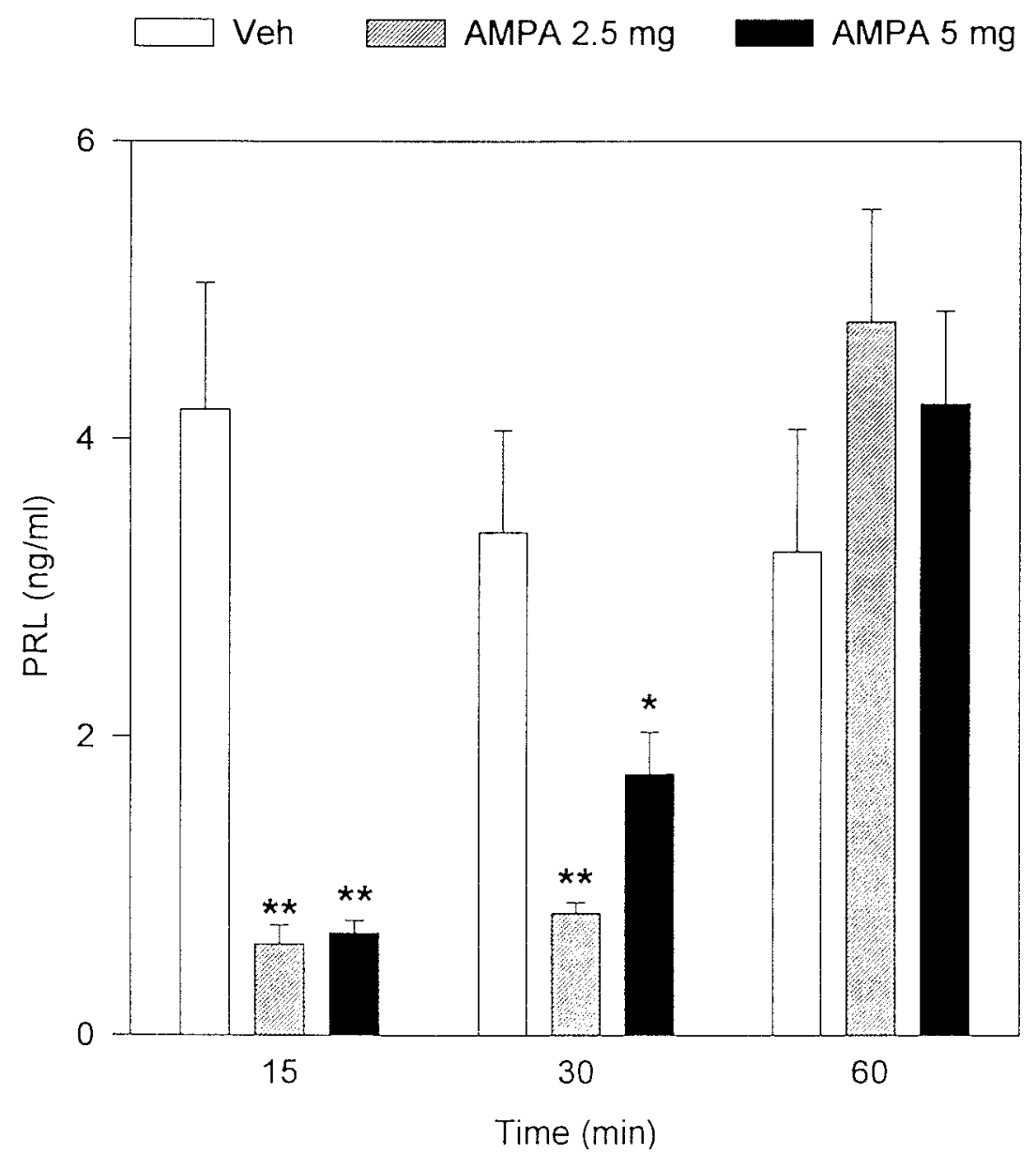

Figure 1 Serum PRL concentrations in 23-day-old male rats 15, 30 and 60 min after i.p. administration of vehicle (open bars) or AMPA (hatched bars: $2.5 \mathrm{mg} / \mathrm{kg}$; solid bars: $5 \mathrm{mg} / \mathrm{kg}$ ). Values are given as means \pm S.E.M. (10 animals per group). ${ }^{*} P \leq 0 \cdot 05,{ }^{* *} P \leq 0 \cdot 01 \mathrm{vs}$ vehicle-injected group (two-way ANOVA followed by Tukey's test).

Effects of AMPA on PRL secretion by hemipituitaries in vitro (experiment 4)

PRL concentrations in media were significantly higher at $120 \mathrm{~min}$ than at $60 \mathrm{~min}$ of incubation $(P \leq 0 \cdot 01$, two-way ANOVA). Incubation of pituitary tissue in the presence of AMPA failed to inhibit PRL release. Furthermore, the analysis of interactions indicated a significant increase $(P \leq 0 \cdot 01) 120 \mathrm{~min}$ after incubation with the lowest dose tested $\left(10^{-8} \mathrm{M}\right)$ (Table 3$)$.

Effects of changes in dopaminergic tone on the inhibitory action of AMPA on PRL secretion (experiment 5)

Domperidone (antagonist of dopaminergic D2 receptors) prompted a clearcut increase $(P \leq 0 \cdot 01$, two-way ANOVA) in serum PRL concentrations. The analysis of interactions showed that the inhibitory effect of AMPA disappeared in domperidone-treated rats (Table 4).
a-MPT (a blocker of tyrosine hydroxylase that reduced dopamine synthesis) significantly increased serum PRL concentrations and abolished the inhibitory effect of AMPA (Table 4). In contrast, animals pretreated with DDC (inhibitor of dopamine- $\beta$-hydroxylase) showed a significant reduction in serum PRL concentrations. In these animals, a further decrease in PRL concentrations was induced by AMPA administration (Table 4).

\section{Effects of AMPA on serotonin-stimulated PRL secretion} (experiment 6)

Serum PRL concentrations increased significantly after administration of fluoxetine and 5 -HTP $(P \leq 0 \cdot 01$, twoway ANOVA). The analysis of interactions between treatments evidenced that the serotonin-stimulated PRL release was not inhibited by AMPA (Table 5). 
Table 1 Serum PRL concentrations in 5-, 10- and 23-day-old male rats decapitated $15 \mathrm{~min}$ after AMPA administration. Values are given as means \pm S.E.M. (10-12 animals per group)

\begin{tabular}{|c|c|c|}
\hline & Treatment & PRL (ng/ml) \\
\hline \multicolumn{3}{|l|}{ Age (days) } \\
\hline \multirow[t]{3}{*}{5} & Vehicle & $2 \cdot 08 \pm 0 \cdot 46$ \\
\hline & AMPA (1 mg/kg) & $1 \cdot 42 \pm 0 \cdot 08$ \\
\hline & AMPA $(2.5 \mathrm{mg} / \mathrm{kg})$ & $1 \cdot 89 \pm 0 \cdot 28$ \\
\hline \multirow[t]{3}{*}{10} & Vehicle & $1 \cdot 51 \pm 0 \cdot 22$ \\
\hline & AMPA (1 mg/kg) & $1 \cdot 03 \pm 0 \cdot 10$ \\
\hline & AMPA $(2.5 \mathrm{mg} / \mathrm{kg})$ & $1 \cdot 36 \pm 0 \cdot 20$ \\
\hline \multirow[t]{3}{*}{23} & Vehicle & $9 \cdot 37 \pm 2 \cdot 17$ \\
\hline & AMPA (1 mg/kg) & $3.63 \pm 0.57^{* *}$ \\
\hline & AMPA $(2.5 \mathrm{mg} / \mathrm{kg})$ & $2 \cdot 97 \pm 0 \cdot 44^{* *}$ \\
\hline
\end{tabular}

${ }^{* * P} \leqslant 0.01$ vs vehicle-injected group (two-way ANOVA followed by Tukey's test).

Table 2 Serum PRL concentrations in 23-day-old males injected with vehicle, NBQX $(0.50 \mathrm{mg} / \mathrm{kg}$ at $-60 \mathrm{~min}), \mathrm{MK}-801$ $(0.25 \mathrm{mg} / \mathrm{kg}$ at $-60 \mathrm{~min})$, AMPA $(2.5 \mathrm{mg} / \mathrm{kg}$ at $-15 \mathrm{~min})$, NBQX+AMPA or MK-801+AMPA. Values are given as means \pm S.E.M. (10 animals per group)

PRL (ng/ml)

$\begin{array}{ll}\text { Treatment } & \\ \text { Vehicle } & 5 \cdot 27 \pm 0 \cdot 81^{\mathrm{a}} \\ \text { NBQX } & 9 \cdot 57 \pm 2 \cdot 18^{\mathrm{a}} \\ \text { MK-801 } & 2 \cdot 32 \pm 0 \cdot 26^{\mathrm{b}} \\ \text { AMPA } & 3 \cdot 11 \pm 0 \cdot 46^{\mathrm{b}} \\ \text { NBQX+AMPA } & 5 \cdot 59 \pm 1 \cdot 17^{\mathrm{a}} \\ \text { MK-801+AMPA } & 1 \cdot 41 \pm 0 \cdot 19^{\mathrm{c}}\end{array}$

Groups with different superscript letters were statistically significant $(P \leqslant 0 \cdot 05$, one-way ANOVA followed by Tukey's test).

Table 3 PRL secreted by hemipituitaries incubated in the presence of different concentrations of AMPA. Values are given as means \pm S.E.M. (10-12 hemipituitaries per group)

PRL (ng/ml)

\begin{tabular}{|c|c|c|}
\hline & \\
\hline & $60 \min$ & $120 \min$ \\
\hline DMEM & $0.09 \pm 0.01$ & $0 \cdot 18 \pm 0.02$ \\
\hline AMPA $\left(10^{-6} \mathrm{M}\right)$ & $0 \cdot 11 \pm 0 \cdot 01$ & $0 \cdot 16 \pm 0 \cdot 02$ \\
\hline AMPA $\left(10^{-7} \mathrm{M}\right)$ & $0.14 \pm 0.02$ & $0 \cdot 30 \pm 0.05$ \\
\hline AMPA $\left(10^{-8} \mathrm{M}\right)$ & $0 \cdot 16 \pm 0.02$ & $0.43 \pm 0.07^{* *}$ \\
\hline
\end{tabular}

${ }^{* *} P \leqslant 0 \cdot 01$ vs DMEM (two-way ANOVA followed by Tukey's test).

Effects of systemic administration of $A M P A$ and NBQX on $P R L$ secretion in adult male rats (experiment 7)

In freely moving adult male rats, serum PRL concentrations showed a tendency to decrease during the sampling period. Neither AMPA nor NBQX administered systemically affected PRL secretion (data not shown).
Table 4 Effects of AMPA ( $2.5 \mathrm{mg} / \mathrm{kg}$ at $-15 \mathrm{~min})$ in 23-day-old male rats with or without pretreatement with domperidone ( $1 \mathrm{mg} / \mathrm{kg}$ at $-60 \mathrm{~min}), \alpha$-MPT $(250 \mathrm{mg} / \mathrm{kg}$ at $-180 \mathrm{~min}$ ) or DDC $(500 \mathrm{mg} / \mathrm{kg}$ at $-180 \mathrm{~min})$. Values are given as means \pm S.E.M. (10 animals per group)
Treatment

$-60 \mathrm{~min}$

Vehicle

Vehicle

Domperidone

Domperidone

$-180 \mathrm{~min}$

Vehicle

Vehicle

$\alpha$-MPT

$\alpha-M P T$

DDC

DDC

in

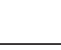

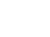

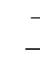

$-15 \mathrm{~min}$

+ AMPA

+vehicle

+ AMPA

$-15 \min$

+vehicle

+ AMPA

+ vehicle

+ AMPA

+vehicle

+ AMPA
+ vehicle
PRL (ng/ml)

$$
\begin{aligned}
& 4 \cdot 69 \pm 2 \cdot 24 \\
& 1 \cdot 78 \pm 0 \cdot 31^{\text {** }}
\end{aligned}
$$

$56 \cdot 53 \pm 12 \cdot 16^{\mathrm{a}}$

$39 \cdot 73 \pm 5 \cdot 81^{a}$

$$
\begin{aligned}
12 \cdot 84 & \pm 2 \cdot 13 \\
4 \cdot 34 & \pm 1 \cdot 56^{\star *} \\
27 \cdot 49 & \pm 3 \cdot 05^{a} \\
21 \cdot 34 & \pm 2 \cdot 88^{a} \\
2 \cdot 08 & \pm 0 \cdot 33^{a} \\
1 \cdot 21 & \pm 0 \cdot 11^{a * *}
\end{aligned}
$$

a $P \leqslant 0.01$ vs corresponding vehicle-injected group; ${ }^{* *} P \leq 0.01$ vs corresponding group not injected with AMPA (two-way ANOVA followed by Tukey's test).

Table 5 Effects of AMPA ( $2.5 \mathrm{mg} / \mathrm{kg}$ at $-15 \mathrm{~min})$ in 23-day-old male rats with or without pretreatment with fluoxetine $(\mathrm{Fx})$ and 5 -HTP (10 and $100 \mathrm{mg} / \mathrm{kg}$ respectively, at $-60 \mathrm{~min}$ ). Values are given as means \pm S.E.M. (10 animals per group)

\begin{tabular}{lr} 
& \multicolumn{1}{c}{ PRL $(\mathrm{ng} / \mathrm{ml})$} \\
\cline { 2 - 2 } Treatment & \\
Vehicle+vehicle & $6 \cdot 92 \pm 1 \cdot 68^{\mathrm{a}}$ \\
Vehicle+AMPA & $1 \cdot 46 \pm 0 \cdot 20^{\mathrm{b}}$ \\
Fx+5-HTP+vehicle & $44 \cdot 28 \pm 6 \cdot 13^{\mathrm{c}}$ \\
Fx+5-HTP+AMPA & $55 \cdot 87 \pm 9 \cdot 94^{\mathrm{c}}$ \\
\end{tabular}

Groups with different superscript letters were significantly different $(P \leq 0 \cdot 01)$ (two-way ANOVA followed by Tukey's test).

Effects of i.c.v. administration of NBQX on PRL secretion in adult male rats (experiment 8 )

Vehicle-injected animals sampled for 3 or $6 \mathrm{~h}$ showed pulsatile PRL secretion (pulse frequency: $4 \cdot 77 \pm 0 \cdot 4$ pulses $/ 6 \mathrm{~h}$; pulse duration: $63 \pm 4 \cdot 7 \mathrm{~min}$; pulse amplitude: $5 \cdot 98 \pm 3 \cdot 8 \mathrm{ng} / \mathrm{ml}$; mean PRL levels: $4 \cdot 43 \pm 1 \cdot 12 \mathrm{ng} / \mathrm{ml}$; through levels $1.38 \pm 0.05 \mathrm{ng} / \mathrm{ml}$; area under the curve: $864 \pm 136)$, which remained unaffected after i.c.v. injection of NBQX (20 or $40 \mathrm{nmol}$ ) (data not shown).

\section{Discussion}

The present results clearly demonstrate that activation of AMPA receptors inhibits PRL secretion in prepubertal male rats, probably through a hypothalamic mechanism 
involving the release of dopamine. Antagonization of AMPA receptors with NBQX did not change PRL secretion in males, in contrast with the stimulatory effect reported previously in females (González et al. 1999b), which suggests a possible sexually dimorphic role of AMPA receptors in the control of PRL secretion, a finding also described for GH (González et al. 1999b).

Activation of AMPA receptors had no effect in neonatal rats as significant inhibition of PRL secretion was not observed on days 5 and 10 of life. This finding is in striking contrast with the effects observed on $\mathrm{GH}$, since AMPA significantly stimulated $\mathrm{GH}$ on day 5 (from $15.42 \pm 2.56 \mathrm{ng} / \mathrm{ml}$ to $146 \pm 37 \mathrm{ng} / \mathrm{ml} 15 \mathrm{~min}$ after administration of $1 \mathrm{mg} / \mathrm{kg}$ AMPA) (González et al. 1999a). These results suggest that the acquisition of AMPA receptor-mediated regulatory mechanisms for different pituitary hormones displays a different timing.

In the present study, pulsatile secretory profiles of PRL in adulthood were similar to those previously described (López et al. 1991). Our results indicate that the role of AMPA receptors in the control of PRL secretion disappeared in adulthood, since neither AMPA nor NBQX affected PRL secretion. Absence of effects were observed after systemic or i.c.v. administration of drugs, indicating that the ineffectiveness of these drugs was independent of their ability to cross the brain-blood barrier. Loss of the effects of AMPA on PRL secretion in adult rats is specific since, in the same experimental paradigm, AMPA administration increased GH secretion (González et al. 1999a). Our results in adult male rats rats contradict those of Wagner et al. $(1994 a, b)$ showing that systemic administration of NBQX decreased serum PRL concentrations. Differences may be due to the very high doses of NBQX (20 and $60 \mathrm{mg} / \mathrm{kg}$ ) required to detect this phenomenon.

The precise mechanisms involved in the inhibition of PRL secretion after activation of AMPA receptors have yet to be determined. In theory, an inhibitory effect at pituitary level, an increase in dopamine release or a decrease in the secretion of hypothalamic PRFs might be responsible for the inhibitory effect of AMPA. Despite the presence of AMPA receptors in pituitary gland (Kiyama et al. 1993, Meeker et al. 1994, Bhat et al. 1995, Villalobos et al. 1996), the only pituitary effect observed was a weak stimulatory action after incubation of hemipituitaries with $10^{-8} \mathrm{M}$ AMPA. The results strongly suggest that the activation of AMPA receptors does not affect the secretion of PRL via a pituitary mechanism.

In order to analyse the involvement of dopamine in the inhibitory actions of AMPA, dopaminergic receptors were blocked with domperidone and dopamine synthesis with $\alpha-M P T$. In these experimental paradigms, AMPA failed to decrease PRL secretion, suggesting that an increase in dopamine release might be involved in the action of AMPA. Further experiments are necessary in order to determine whether activation of AMPA receptors also decreased the secretion of PRFs, such as vasointestinal peptide, thyrotrophin-releasing hormone or the newly characterized PRL-releasing peptide (Kato et al. 1978, Fagin \& Neill 1981, Hinuma et al. 1998).

AMPA also failed to reduce PRL secretion in animals pretreated with fluoxetine and 5-HTP. This finding is consistent with our hypothesis that the mechanism behind the action of AMPA involves the release of hypothalamic dopamine since, when dopamine was infused intravenously, elevating its concentration in portal vessels, 5-hydroxytryptamine-induced PRL release was not prevented (Pilotte \& Porter 1981).

The physiological relevance of the inhibitory effect of AMPA on PRL secretion in rats remains to be elucidated. However, the fact that this action is only observed in prepubertal animals opens the possibility that pubertal development might be dependent on the degree of activation of NMDA and AMPA receptors. Activation of NMDA receptors advanced puberty onset through an increase in LH-releasing hormone release (Urbanski \& Ojeda 1987). In contrast, repeated i.c.v. injections of AMPA to immature female rats diminished PRL and oestradiol secretion and delayed puberty (Pinilla et al. 1999b). Since, in these experiments, LH secretion remained unchanged after systemic or i.c.v. administration of AMPA, it is tempting to postulate that the delay of puberty after AMPA treatment is mediated by the decrease in PRL secretion, since it is well known that PRL increased the number of ovarian LH receptors (Advis et al. 1981), the responsiveness to gonadotrophins (Advis \& Ojeda 1978) and advanced the onset of puberty in female and male rats (Clemens et al. 1969, Aguilar et al.1988). Experiments are in progress to determine whether activation of AMPA receptors modifies pubertal development in male rats.

In conclusion, these results demonstrate that activation of AMPA receptors inhibits PRL release in prepubertal male rats, probably through a hypothalamic mechanism involving the release of dopamine.

\section{Acknowledgements}

This study was subsidized by grant PM98-0163 (DGICYT, Spain) and project 1FD97-0696-02 (FEDER). The NIH supplied the RIA materials for PRL determinations. We are indebted to Rocío Campón and Inmaculada Aguilar for their excellent technical assistance.

\section{References}

Abbud R \& Smith MS 1991 Differences in the luteinizing hormone and prolactin responses to multiple injections of kainate, as compared with N-methyl-D,L,-aspartate, in cycling rats. Endocrinology 129 3254-3258.

Advis JP \& Ojeda SR 1978 Hyperprolactinemia-induced precocious puberty in the female rat: ovarian site of action. Endocrinology 103 924-935. 
Advis JP, Richards JS \& Ojeda SR 1981 Hyperprolactinemia-induced precocious puberty. I. Studies on the mechanisms by which prolactin (PRL) enhances ovarian progesterone responsiveness to gonadotropins in prepubertal rats. Endocrinology 108 1333-1342.

Aguilar R, Bellido C, Sánchez-Criado JE \& Aguilar E 1988 Mechanisms of precocious puberty induced in male rats by pituitary grafts. Journal of Reproduction and Fertility 83 879-883.

Bhat GK, Mahesh VB, Chu ZW, Chorich LP, Zamorano PL \& Brann DW 1995 Localization of the N-methyl-D-aspartate $\mathrm{R}_{1}$ receptor subunit in specific anterior pituitary homone cell types of the female rat. Neuroendocrinology 62 178-186.

Brann DW \& Mahesh VB 1997 Excitatory amino acids: evidence for a role in the control of reproduction and anterior pituitary secretion. Endocrine Reviews 18 678-700.

Carbone S, Szwarcfarb B, Rondina D, Scacchi P \& Moguilevski J 1994 Effect of ovarian hormones on the prolactin response to excitatory amino acid system during sexual maturation. Neuroendocrinology Letters 16 247-255.

Carro E, Pinilla L, Seoane ML, Considine RV, Aguilar E, Casanueva FF \& Diéguez C 1997 Influence of endogenous leptin tone on the estrous cycle and luteinizing hormone pulsatility in female rats. Neuroendocrinology 66 375-377.

Clemens JA, Minagushi H, Storey R, Voogt JL \& Meites J 1969 Induction of precocious puberty in female rats by prolactin. Neuroendocrinology 4 150-156.

Collinbridge GL \& Watkins JC 1994 The NMDA Receptor. Oxford: Oxford University Press.

Donoso A, López F \& Negro-Vilar A 1990 Glutamate receptors of the non-N-methyl-D-aspartic acid type mediate the increase in luteinizing hormone-releasing hormone release by excitatory amino acids. Endocrinology 126 414-420.

Fagin KD \& Neill JD 1981 The effect of dopamine on thyrotropin hormone-induced prolactin secretion in vitro. Endocrinology 109 1835-1840.

González LC, Pinilla L,Tena-Sempere M \& Aguilar E 1999a Regulation of growth hormone secretion by AMPA receptors in infantile, prepubertal and adult rats. Endocrinology 140 1279-1284.

González LC, Pinilla L, Tena-Sempere M \& Aguilar E 1999 b Role of AMPA receptors in the control of anterior pituitary secretion in prepubertal female rats. Journal of Endocrinology 162 417-422.

Greenwood FC, Hunter WM \& Glover JS 1963 The preparation of 131-I-labelled human growth hormone of high specific radioactivity. Biochemical Journal 89 114-123.

Haggi E \& Aoki A 1981 Prolactin content in rat pituitary gland. RIA of prolactin after different extraction procedures. Acta Endocrinologica $97338-342$.

Hinuma S, Habata Y, Fujii R, Kawamata Y, Hosoya M, Fukusumi S, Kitada C, Masuo Y, Asano T, Matsumoto H, Sekiguchi M, Kurokawa T, Nishimura O, Onda H \& Fujimo M 1998 A prolactin-releasing peptide in the brain. Nature 393 272-276.

Kato Y, Iwasaki Y, Iwasaki J, Abe H, Yanaihara N \& Imura H 1978 Prolactin release by vasoactive intestinal peptide in rats. Endocrinology 103 554-558.

Kiyama H, Sato K \& Tohyama M 1993 Characteristic localization of non-NMDA type glutamate receptor subunits in the rat pituitary gland. Molecular Brain Research 19 262-268.

López FJ, Sánchez-Criado JE \& Negro-Vilar A 1991 A physiological role for sporadic interruptions of the dopaminergic tone in the genesis of big mass prolactin pulses. Endocrinology 129 1471-1480.

Luderer U, Strobl FJ, Levine JE \& Schwartz NB 1993 Differential gonadotropin responses to $\mathrm{N}$-methyl-D,L,-aspartate in metestrous, proestrous, and ovariectomized rats. Biology of Reproduction $\mathbf{4 8}$ 857-866.

Martin AI, Fernandez-Ruiz J \& Lopez Calderon A 1995 Effects of catecholamine synthesis inhibitors and adrenergic receptor antagonists on restraint-induced LH release. Journal of Endocrinology $144511-515$
Meeker RB, Greenwood RS \& Hayward JN 1994 Glutamate receptors in the rat hypothalamus and pituitary. Endocrinology 134 621-629.

Negro-Vilar A, Ojeda SR, Advis JP \& McCann SM 1979 Evidence for noradrenergic involvement in episodic prolactin and growth hormone release in ovariectomized rats. Endocrinology 105 86-91.

Neill JD \& Nagy GM 1994 Prolactin secretion and its control. In The Physiology of Reproduction, pp 1833-1860. Eds E Knobil \& JD Neill. New York: Raven Press.

Pilotte NS \& Porter JC 1981 Dopamine in hypophysial portal plasma and prolactin in systemic plasma of rats treated with 5-hydroxytryptamine. Endocrinology 108 2137-2141.

Ping L, Mahesh VB, Bhat GK \& Brann DW 1997 Regulation of gonadotropin-releasing hormone and luteinzing hormone secretion by AMPA receptors. Neuroendocrinology 66 246-253.

Pinilla L, Tena-Sempere M \& Aguilar E 1995 The role of excitatory amino acid pathways in the control of pituitary function in neonatally oestrogenized male rats. Journal of Endocrinology 147 $51-57$.

Pinilla L, González D, Tena-Sempere M, Aguilar R \& Aguilar E 1996 Effects of N-methyl-D-aspartate and kainic acid on prolactin secretion in prepubertal female rats. European Journal of Endocrinology 135 464-468.

Pinilla L, Tena-Sempere M, Aguilar R \& Aguilar E 1998 Effects of $\mathrm{N}$-methyl-D-aspartic acid and kainic acid on prolactin secretion in hyper- and hypoprolactinaemic conditions. European Journal of Endocrinology 138 460-466.

Pinilla L, Gonzalez L, Tena-Sempere M, Dieguez C \& Aguilar E 1999a Gonadal and age-related influences on NMDA-induced growth hormone secretion in male rats. Neuroendocrinology 69 11-19.

Pinilla L, Gonzalez L, Tena-Sempere M \& Aguilar E 1999 b Efectos de la administración intracerebroventricular (i.c.v.) de AMPA durante el periodo prepuberal a ratas hembras. XXX Meeting Sociedad Española de Ciencias Fisiológicas. Journal of Physiology and Biochemistry 55 (Abstract).

van den Pol A, Waurin J \& Dudek F 1990 Glutamate, the dominant excitatory transmitter in neuroendocrine regulation. Science $\mathbf{2 5 0}$ $1276-1278$.

Spergel DJ, Krsmanovic L, Stojilkovic S \& Catt K 1994 Glutamate modulates calcium and gonadotropin-releasing hormone secretion in immortalized hypothalamic GT1-7 neurons. Neuroendocrinology 59 309-317.

Urbanski HF \& Ojeda SR 1987 Activation of luteinizing hormonereleasing hormone release advances the onset of female puberty. Endocrinology 46 273-276.

Villalobos C, Nuñez L \& García-Sancho J 1996 Functional glutamate receptors in a subpopulation of anterior pituitary cells. FASEB Journal 10 654-660.

Wagner EJ, Moore KE \& Lookingland KJ 1994a Neurochemical evidence that AMPA receptor-mediated tonic inhibition of hypothalamic dopaminergic neurons occurs via activation of inhibitory neurons. Brain Research 660 319-322.

Wagner EJ, Moore KE \& Lookingland KJ $1994 b$ Non-NMDA receptor-mediated regulation of hypothalamic dopaminergic neurons in the rat. European Journal of Pharmacology 254 105-112.

Zanisi M, Galbiati M, Messi E \& Martini L 1994 The anterior pituitary gland as a possible site of action of kainic acid. Proceedings of the Society for Experimental Biology and Medicine 206 431-437.

Zuo Z, Mahesh VB, Zamorano PL \& Brann DW 1996 Decreased gonadotropin-releasing hormone neurosecretory response to glutamate agonists in middle-aged female rats on proestrus afternoon: a possible role in reproductive aging? Endocrinology 137 2334-2338.

Received 8 December 1999

Revised manuscript received 1 March 2000 Accepted 18 May 2000 